\title{
Customer Service Experience and the Reputation of Hotels in Uyo, Akwa Ibom State, Nigeria.
}

\author{
Dr. Uduak E. Joseph (PhD), Dr. Sam G. Etuk (PhD) and Ini Smart Udoh* \\ asifonmfonmma@yahoo.com \\ Department of Marketing, University of Uyo, Uyo- 520001, Nigeria \\ Department of Marketing, University of Uyo, Uyo- 520001, Nigeria
}

\begin{abstract}
The reputation of service businesses is made up of what others think and feel about the business. The main aim of this study is to ascertain the level of relationship that exist between customer service experience and the reputation of hotels in Uyo, Akwa Ibom State. The survey design as the main research design was adopted for the study. The population for this study consists of all the persons that were encountered at 196 hotels in Uyo, duly registered by the Akwa Ibom State tourism development board as at the time of this study. The total sample size for the study which made up the number of copies of questionnaire distributed was 384. Data was analyzed using the Regression analysis. Findings showed that Peace of Mind was the important independent variable in the study that had the highest impact on Hotel Reputation, it was followed by the variable customer involvement, moment of truth and customer recognition. The least important independent variable in the regression model were Hedonics because it had the smallest impact on Hotel Reputation. And its impact was not statistically significant, as their p-values was greater than 0.05 . it was recommended that hotels should work on their reputation, by recognizing the roles that customer service experience plays on their patronage strength. Recognizing these roles can also enhance better customer post service experience behavior like favorable word of mouth recommendations, customer loyalty, and satisfaction among customers.
\end{abstract}

Published by IJRP.ORG. Selection and/or peer-review under responsibility of International Journal of Research Publications (IJRP.ORG)

Keywords: Customers; Experience; Hotels; Reputation, Services.

\section{Introduction}

To create a good business reputation takes time and great effort and such can be lost at an instant. The reputation of service businesses is made up of what others think and feel about the business, what they've heard about the business and the opinions they've gathered about the business from other sources, whether true or not. 
In Akwa Ibom State of Nigeria, hotel business is a subset of the hospitality industry, offering accommodation for lodging, resting, dinning, seminars, conferences, meeting venues, entertainment among other services. This industry largely depends on repeated customers visit for survival as well as their recommendations and referrals to project their positive image and reputation to a wider prospect. Hotel services is thus seen as a more experience-based service industry and to sustain a favorable reputation among customers and prospective customers, selling services are not enough to differentiate offerings but it is required that hoteliers provide memorable experiences to the hotel guests (Khan, Garg and Rahman, 2015). This is because customers develop sentiments that may reflect their rational, emotional, physical and sensory involvement with the service offerings through various interactions with the service provider (Kandampully, Zhang, and Jaakkola, 2018). The awaking consciousness in customers has sharpened their knowledge horizon, thereby arming them to the extent that customers are readily prepared to challenge bad service rendered to them (Oladele, Yakibi, Akinruwa and Ajayi, 2019). This increase in knowledge on the path of customers has reshaped end user service expectations from service providers (Oladele, 2011). Thus, it can be said that service customers are rational and emotional decision makers.

Customer Experience reflects the customer's journey through all interactions with the hotel services, from the pre-consumption, consumption and post-consumption phases (Kandampully and Solnet, 2015). It is, therefore, more than the result of a single encounter and is affected by every episode of the customer's interaction process with the service provider (Verhoef, Lemon, Parasuraman, Roggeveen, Tsiros, and Schlesinger, 2009) and is often co-created through interactional activities among the actors in the course of the service delivery (Ponsignon, Klaus, and Maull, (2015). Customer experience in hotel settings is not only gathered from their encounter with the foods, beverages, accommodation services and entertainment but also from an unlimited amount of supporting features and processes, such as the provision of internet services, the physical settings, design and system layouts, room entertainment, including customers interactions with hotel personnel (Kandampully and Solnet, 2015). All of which builds up to their service encounter story.

Zeithmal and Bitner (2003) and Sarpong (2016) refer to this phase of service encounter as the "moment of truth". This process in the service consumption stage could leave enduring impressions and memories of either pleasant or unpleasant encounters from the customers perspective (Weeks, 2015). It is an enquiry into customer service experiences gathered during service encounters at hotels as it is most likely to influences the reputation of the hotel brand, that forms the focus of this study. The study adopts and modifies Otto and Ritchie (1996), Amoah (2016); Khan, Garg and Rahman, (2015) and Maklan and Klaus (2011) customer service experience dimensions scale (hedonics, peace of mind, involvement, moment of truth, and 
recognition) to measure against hotel reputation. These scales have been validated across service research in banking, luxury goods, tourism and hospitality, industrial economics among others.

\subsection{Statement of the problem}

Understanding the notion of how customers perceive hotel services when they experience it is becoming a prerequisite for best service provision. The Customers' service experience is most likely to determine the reputation of a hotel service provider and the level of quality provided often determines what customers and consumers think of their service offering. Thus, this can lead to its reputation being enhanced or downgraded. In spite of the apparent increase in consumer behavior related research and the growing prospect of the hotel service sub sector, there is little empirical research evidence on customer service experience dimensions as they could influence the reputation of hotel businesses. Specifically, the researcher found no study on the relationship between customer service variables and hotel reputation within the hospitality industry in Akwa Ibom State. This study thus finds its basis to investigate this relationship.

\subsection{Objective of the study}

The main aim of this study is to ascertain the level of relationship that exist between customer service experience and the reputation of hotels in Akwa Ibom State. Based on this objective, this study will seek to address the research question on: What significant relationship exist between customer service experience dimensions and the reputation of hotels in Uyo the Akwa Ibom State capital?

\subsection{Hypothesis of the study}

In line with the research question, it is hypothesized that:

$\mathbf{H}_{01}$ : There is no significant relationship between customer service experience dimensions (hedonics, peace of mind, involvement, moment of truth, and recognition) and the reputation of hotels.

\section{Review of related literature.}

\subsection{The Concept of Customer service experience at Hotels}

Customer experience is an important marketing concept aimed at creating a unique, pleasurable and memorable experience for the service customer. Consumer experience study is a relatively new concept, in both theory and practice and has gained larger attention in the recent past, particularly in the last three decades (Verhoef, Lemon, Parasuraman, Roggeveen, Tsiros and Schlesinger, 2009). Klaus and Maklan (2013) are of the view that customer experiences are the collection of customer's cognitive and affective assessment of all direct and indirect encounters with the firm relating to their purchasing behavior. Scholars and marketers 
describe customer service experience as a strategic process for creating holistic customer value, achieving differentiation and sustainable competitive advantage (Jain, Aagja and Bagdare, 2017). Scholars believe that, once defined robustly, customer experience will prove to be a better predictor of customer satisfaction, advocacy and purchasing behavior than Service Quality Dimensions (SERVQUAL). (Prahalad and Ramaswamy, 2004; Schembri, 2006).

Contemporary hospitality research suggests that the traditional dimensions of service quality might not be enough to address the affective and holistic factors required for high-quality overall service experiences (Amoah, 2016). Chen (2007) argues that customers could be delighted through experience quality rather than through the mere provision of service quality, which implies that experience quality goes beyond the notion of service quality (Lemke, Clark and Wilson, 2011). Thus, there is evidence of a shift from "commoditization" to "personalization" co-created consumption experiences. There is a wider agreement that providing positive customer experiences is essential for achieving competitive advantage, customer satisfaction, differentiation, image, loyalty and positive word-of-mouth communications (Jain, Aagja and Bagdare, 2017).

According to Otto and Ritchie, (1996), they emphasize that the benefits of experience quality is experiential, hedonic, or symbolic, while service quality benefits are functional or utilitarian in nature. They posit four experience quality dimensions namely; hedonics, peace of mind, the moment of truth, involvement, and recognition (Otto and Ritchie, 1996).

- Hedonism is associated with the fun factor that creates a positive atmosphere for the customers (Josiam and Henry, 2014). It includes programs that will engage hotel guests in what they like to do, that might create fun and influence the perception of the experience being hedonic (Amoah, 2016). Furthermore, enjoying good food in a restaurant surrounded by beautiful scenery, or enjoying the physical experience of walking around the vicinity could be seen as utilizing resources in producing and consuming highly worthwhile and memorable experiences (Kim, Ritchie and McCormick, 2012).

- Peace of mind refers to a state of mental and emotional calmness, undisturbed by worries, anxieties, or fear (Sasson, 2014). According to Amoah, (2016) three factors can provide customers with peace of mind. These include safety, security, and privacy.

- Involvement is a customer's desire to have a choice and control in the service offering, and the demand to be educated, informed, and incorporated with a sense of mutual co-operation and participation (Chen and Chen, 2010). Participation on the other hand could refer to the act of customer engagement, thus making them part of the experience creation.

- Recognition is associated with feeling important, confident, and being taken seriously at all times (Wu and Li, 2014; Otto and Ritchie, 1996). Recognition can result from social value/self-concept and 
employees' attitudes towards hotel guests (Amoah, 2016). A typical example of social value could be staying only at a five-star hotel because of its social value, prestige, or image, or because such hotels are associated with a certain class of people. Hotel guests may also choose particular accommodation because it provides sophisticated experiences (Walls, 2013).

- Moment of truth: The term moment of truth is synonymous with service encounter. It is often referred to as the time during which a consumer directly interacts with a service (Payne, Christopher, Clark and Peck, 2003). This interface between customers and the service provider is also referred to as, the "moment of truth" (Sarpong, 2016). The basis for which service encounters are referred to as moments of truth stems from considering the attributes of services being rendered, its intangible nature as well as the customer participation in the service production process. All of which have relevance in the service contact process to the customer, which in turn influence the service customers' perception about the quality and experience of the service (Strauss and Mang 1999).

\subsection{The Concept of Hotel Reputation}

Reputation is a vital component of a hotel's value and a key measure of performance, functioning as a mechanism which decreases uncertainty for customers (Qoura and Khalifa, (2013). Corporate reputation is a powerful influence on whether consumers become customers (Helm, 2006). Reputation is an important factor that influences consumers experience. It is suggested that hospitality service providers with good reputation offer customers good value, communicate honestly and are ethical and well managed (Ou, Abratt and Dion, 2006).

Hotel reputation emerges as an intangible asset which differentiates a hotel from others and attracts customers to repurchase and willingly pay higher price for products (Loo and Davies, 2006; Jayawardena, Lawlor, Grieco, Savard, and Tarnowski, (2013). On the other hand, the collection of experience gained by customers during and after service encounter at hotels can influence the reputation of the Hotel across a wider range of prospects. The implication of this is that customers go after services of hotels with favorable reputation and are more loyal to those they perceive as having a favorable reputation.

In an attempt to enhance guests experience and an impressive reputation in the minds of customers, hoteliers try to maintain good relationships with their guests during their stay in the hotel, correct or at least state the awareness of negative issues that occurred during the stay and also leave the impression of a hospitality service provider that really cares about providing its customers with the ultimate hotel experience (Ajanović, Cizel and Çizel, 2015). The outcomes of reputation built up from customers' experiences could be Word of mouth communication, customer satisfaction and the hotels' image. 
- Word of Mouth Communication: Word-of-mouth refers to the passing of information by verbal means, especially recommendations, referrals and general information, in an informal, person-to-person manner (Havaldar and Dash, 2000). Henning-Thurau (2004) defines word of mouth as any comments (positive or negative) received or spread by the actual, former or potential customer about any service (Jeong and Jang, (2011). Word of mouth is the process in which people shares their experience and views about any particular service brand which has an influence on consumer's buying behavior (Ha and Jang, 2010). Word-of-mouth communication is important for a client during the pre-purchase and post-purchase time frames, to decrease the perceived risks of a purchase. It is also highly valued by marketers and believed that this form of communication has valuable source credibility (Havaldar and Dash, 2000). Unfavorable WOM communication may ruin the company, on other hand positive WOM communication may take the company to be a leader in its market segment. People who have more knowledge or opinion about a service encounter may influence the buying behavior of prospective customers when they spread word of mouth about any service (Muzamil, Qadeer, Makhija and Jahanzeb, 2018).

- Customer satisfaction; customer satisfactions have important relationships in customer's repurchasing decision process (Nikou, Selamat, Yusoff, and Khiabani, 2016). satisfaction includes not only the feelings associated with the purchasing process, but also the atmosphere before and after the execution of purchases, that customers are exposed to experience (Biesok, and Wyród-Wróbel, 2011). When Customer's expectations are met satisfaction is said to occur. According to Biesok, and Wyród-Wróbel (2011) satisfaction or dissatisfaction is described as a subjective feeling and a result of specific experiences of individuals' perceptions and emotions. This satisfaction or dissatisfaction reflects a feeling connected with the completed or unfulfilled expectations in relation to a particular service. The satisfaction felt by the client, is associated with the experience of his positive impressions, and conversely will be linked to dissatisfaction with the lack of positive incentives.

- Hotel Image; according to Qoura and Khalifa, (2013) the word image can mean different things to different people. Boo (2003) uses the concept of image in a broad context, defining it as the expression of all objective knowledge, impressions, prejudice, and emotional thoughts an individual or group has of a particular object or place'. Hotel image is believed to play an important role on a customer's decision to use a hotel and is mainly derived from customers past experiences (Nikou, Selamat, Yusoff, and 
Khiabani, (2016). Thus, a customer's experience with the hotels' services is considered to be the factor most influential in determining their image of the hotel (Kandampully and Suhartanto 2000).

- According to Ou et al., (2006), hotel reputation is a relatively stable, long term, collective judgment by outsiders about the service providers' actions and achievements. This study thus modifies and adopt customer service experience dimensions by Otto and Ritchie, (1996) in a quest to understand their influence on the reputation of hotels. It is recognized that customer experience impressions are gained from the foundations of their expectations and actual encounter. In this light, the conceptual frame work for this study is thus represented as:

\section{Customer Service Experience Variables}

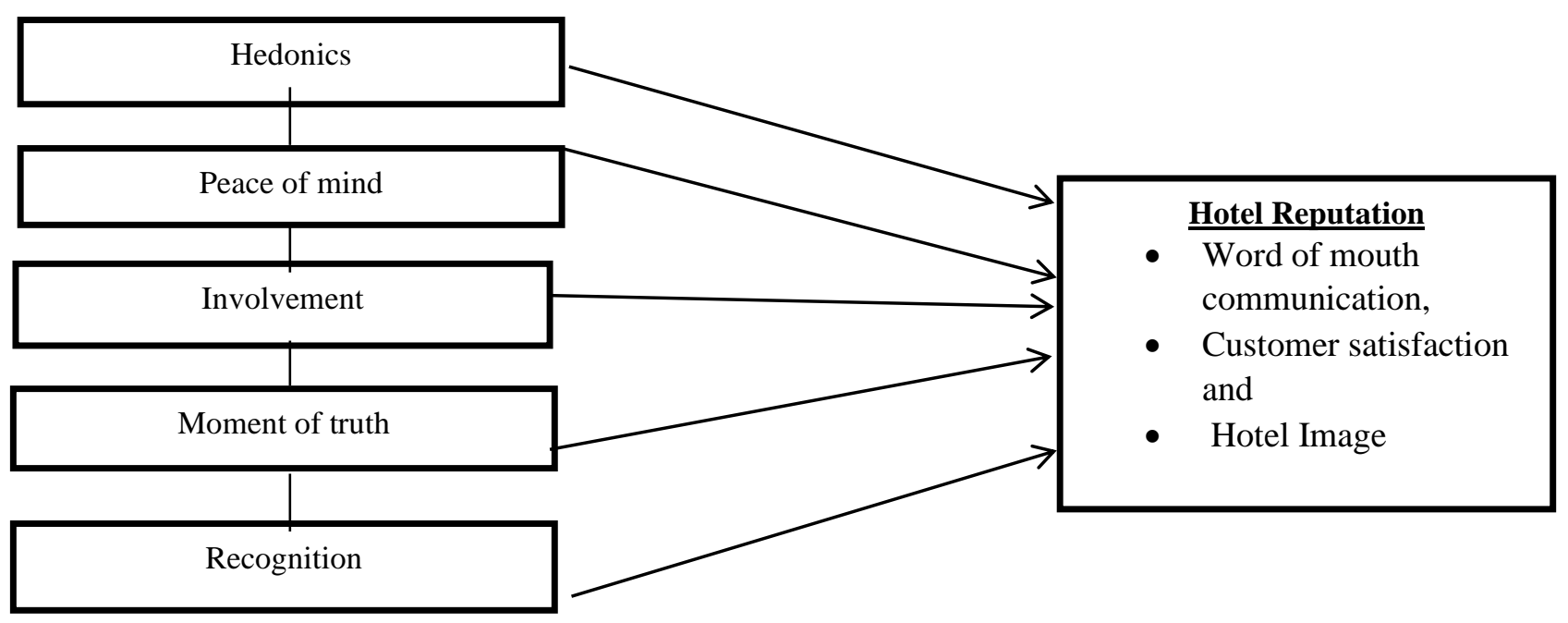

Figure 1. (a) Conceptual Framework on Customer service Experience and Hotel Reputation

\subsection{Theoretical Framework}

This study is anchored on Pine and Gilmore's (1998) Experience Economy theory. The experience economy theory was first found by Pine and Gilmore (1998) in their article on the Experience Economy, they described the experience economy as the next economy following the agrarian economy, the industrial economy, and the service economy. Pine and Gilmore (1998) expressed that businesses must orchestrate memorable events for their customers, and that memory itself becomes the product which they called the "experience". The theory of experience economy has become the main underpinning for customer experience management since its mention and has found its focus in business, tourism, architecture, nursing, urban planning and other fields. 
In all fields that have adopted the theory, the level of abstraction has been that all consumption can be understood in experiential terms.

The present study anchors on this theory on the basis that in-service marketing related studies directed at customer service experience in hotels, the value of all services is co-created or co-produced through the interaction between consumers and service providers. Experience is gathered from customer interaction with the hotel environment, hotel employees, complain channels, as well as their interactions with other service offerings within the hotel space like restaurants, bar, security, laundry, game outfits among others. Hotel Customers' encounter on these interactions develop into experiences they gather whether positive or negative about the hotel services. This in turn has an influence on their testimony of the services to a wider market prospect and impacts on their reputation. Making service providers focus on not just on the product the offer, but on psychologically impacting on the customers interactions with their services.

\subsection{Empirical Framework}

In a study on Experience quality dimensions and customer perceptions, a case study of guesthouses in Ghana carried out by Amoah (2016). The researcher aimed at examining the dimensions of experience quality, determine customers' perceptions of experience quality and investigate various relationships between the experience quality dimensions and experience quality; between experience quality and satisfaction; and between satisfaction and behavioral intentions. A structural equation model was employed to confirm these relationships. The researcher adopted a survey research method and a self-administered survey questionnaire containing 16 items on a 5-point Likert scale was used to collect the needed data. The sample size for the study was made up of 541 respondents from four cities in Ghana (Accra, Cape Coast, Kumasi, and Koforidua). Using stratified sampling, 51 guesthouses were selected for the study. Exploratory factor analysis (EFA) was applied in an attempt to identify the underlying dimensions in guests' perceptions of experience quality. Principal component analysis with VARIMAX rotation was adopted as the basis of factor extraction and only items with a minimum loading of 0.300 were retained. Four factors resulted from the Exploratory Factor Analysis (EFA). These factors were commensurate with the anticipated factors and were termed Peace of mind, Recognition, Hedonics, and Involvement. Finding indicate that experience quality has a positive relationship with customer satisfaction. Important pointers from the study showed that customers are no

longer merely satisfied by high levels of service quality, but desire overall experiences of high quality. Second, although no consensus exists in terms of what the dimensions of experience quality are, experience quality is noted as an important competitive differentiation strategy. Third, experience quality associated with 
guesthouses comprises hedonics, peace of mind, involvement, and recognition and are important as part of overall experience quality.

Nitin, Seetharaman, Vidyalakshmi and Alison (2018) in their study on the Changing Dimensions of Customer Experience, had a main objective of identifying present and future trends, concerning Customer Experience, aimed at guiding companies to adapt to today's customers. They researchers adopted both qualitative and quantitative analysis method in the study. An online survey was conducted on a sample size of 108 respondents, with a questionnaire containing 17 items consisting of present factors (instant gratification, custom content, concerned employees, social commence, Special offers and ambiance, Physical contact with product), measured on a 5-point Likert scale. A step-wise regression analysis was utilized in analyzing the relationship between constructs. Findings showed that all the constructs had a significant relationship. Findings further showed that in present day, Consumers and customers are in control, thus service organizations aiming to succeed should reach out to customers for feedback and continuously improvise. The authors emphasized that as demands continuously evolve, it is essential for hotel and restaurant service providers to keep up with the current trends and identify future trends in order to deliver the best value to customers.

\section{Methodology}

Based on the objective of this study, focused on the influence of customer service experience dimensions on the reputation of hotels, the research method is as follows;

Research design; The study utilizes the survey design as the main research design. The survey design according to Zikmund (2000) is a design which allows information to be gathered from a sample of people or organizations by the use of questionnaire.

The study area; Uyo the Akwa Ibom state capital was adopted as the study area. The proximity of the study area to the researcher facilitated the collection of needed data within the time frame for the study. The State is made up of 31 local government areas with Uyo as the State capital. Furthermore, it is divided into three Senatorial districts namely Uyo, Eket and Ikot Ekpene named after the major towns in the state.

Population of the study; The population for this study consist of all the persons that were encountered at the 196 hotels in Uyo, duly registered by the Akwa Ibom State tourism development board as at the time of this study. This is irrespective of the demographic variables or social status. As it was not possible to have a clear figure of people in this category, the population of the study was treated as large and practically impossible to use the whole population for this study. 
Sample size determination; To this end, a sample of the population was selected to represent the population. Hotels in Uyo that have rentable rooms ranging between 20 and 40 were considered. A pilot survey revealed that there are thirty-nine (39) hotels in this category across Uyo. These hotels are classified as two stars and three stars respectively. 30 copies of questionnaire were distributed among hotel customers encountered during the pilot survey. The confidence interval method was utilized at $95 \%$ level of confidence which is given as 1.96, at a 5\% (0.05) tolerable error. Thus, to arrive at an appropriate sample size for the study, responses to the questions allowed the researcher to generate values for ' $\mathrm{P}$ ' (positive) and generate values for 'Q' (negative), for the Top-man formula (refer to Appendix 1). The pilot study revealed that at least fifty percent $(50 \%)$ of the population would always expect an average rating of all the variables under study. Thus, the sample size arrived at was 384 respondents.

Sampling technique; Purposive sampling technique was adopted in selecting the hotel customers for this study. This sampling technique was adopted due to the need to access the type of information and data needed for this study, from the target respondents. The number of hotel customers for each hotel was arrived at by dividing the total number of sample size for the study (384), obtained from applying the confidence interval formula from the pilot study by 39 hotels in the category of a 3 -Star and a 2-Star hotel in Uyo. This result made up the number of Customers per hotel that were surveyed (10 respondents at each hotel).

Sources of Data; The main source of data that were utilized in this study are primary data. On the other hand, published literatures on related topics, beneficial to this study were also utilized to enrich the study and give it an empirical backing. The primary data were collected through the use of structured copies of questionnaire.

Research instrument; The main instrument that was use for the study is a research questionnaire titled "Customer Service Experience Quality Questionnaire (CSEQ)". The instrument sought information aimed at measuring Customer service experience dimensions influence on hotel reputation in Uyo.

Data Collection Method; The study's questionnaire consists of multiple-choice questions and the predictor (hedonics, peace of mind, involvement, moment of truth, and recognition) and criterion (hotel reputation) variables were measured on a ' 5 ' point Likert scale.

Administration of Research Instrument; As the Researcher could not be at all places/locations at a time, help was sought in administering copies of questionnaire to hotel customers within the research period. 
Reliability test of the instrument; to test the reliability of the instrument, a pilot survey was conducted. Based on the responses gathered, the Cronbach's alpha was used in testing the reliability of the instrument. The coefficient alphas for all dimensions adopted for this study were;

\section{Table 1. Cronbach's Alpha result}

\begin{tabular}{llll}
\hline S/No. & Variables & No. of Items & Cronbach's Alpha Coefficient \\
\hline 1 & Hedonics & 2 & 0.816 \\
2 & Peace of mind & 2 & 0.667 \\
3 & involvement & 2 & 0.687 \\
4 & Moment of truth & 2 & 0.546 \\
5 & Recognition & 2 & 0.734 \\
6 & Hotel Reputation & 3 & 0.540 \\
\hline & Total & $\mathbf{1 3}$ & $\mathbf{0 . 6 6 5}$ \\
\hline
\end{tabular}

Source: Field survey, 2020.

Given this result the instrument was adjudged reliable enough for the study and seen to be appropriate. Alpha levels of $0.50-0.9$ are normally considered good for such instrument (Rubin and Babbie, 2005).

Data Analysis Technique; to determine the extent of relationship that collectively exist between the customer service experience dimensions (Hedonics $(\mathrm{Hd})=\mathrm{X}_{1}$, peace of mind $(\mathrm{Pm})=\mathrm{X}_{2}$, involvement $(\mathrm{Inv})=\mathrm{X}_{3}$, moment of truth $(\mathrm{Mt})=\mathrm{X}_{4}$, and recognition $\left.(\mathrm{Reg})=\mathrm{X}_{5}\right)$, which are the independent variables and Hotel reputation $(\mathrm{Hr})=\mathrm{Y}$, the dependent variable. The multiple regression analysis was used at a 0.05 level of significance (e).

Model Specification; the functional model for this study is given as;

$\mathrm{Y}=\mathrm{f}\left(\mathrm{X}_{1}, \mathrm{X}_{2}, \mathrm{X}_{3}, \mathrm{X}_{4}, \mathrm{X}_{5}\right)$ equation 1

Recoded to represent the variables it is presented as;

$\mathrm{HR}=\mathrm{f}(\mathrm{Hd}, \mathrm{Pm}$, Inv, Mt, Reg $)$

The multiple regression model that represents the collective influence of the independent variables $\left(X_{1}, X_{2}\right.$, $\left.\mathrm{X}_{3}, \mathrm{X}_{4}, \mathrm{X}_{5}\right)$ on the dependent variable $(\mathrm{Y})$ was expressed in this form;

$\mathrm{Y}=\mathrm{a}_{0}+\mathrm{b}_{1} \mathrm{X}_{1}+\mathrm{b}_{2} \mathrm{X}_{2}+\mathrm{b}_{3} \mathrm{X}_{3}+\mathrm{b}_{4} \mathrm{X}_{4}+\mathrm{b}_{5} \mathrm{X}_{5}+\ldots$ e- $\quad-\quad-\quad-\quad$ equation 2

$\mathrm{Hr}=\mathrm{a}_{0}+\mathrm{b}_{1} \mathrm{Hd}+\mathrm{b}_{2} \mathrm{Pm}+\mathrm{b}_{3} \mathrm{Inv}+\mathrm{b}_{4} \mathrm{Mt}+\mathrm{b}_{5} \mathrm{Reg}+\ldots . \mathrm{e} \quad-\quad-\quad-\quad$ equation 3 


\section{Result of Data analysis}

Out of the 384 copies of questionnaire distributed, 371 copies $(96 \%)$ were returned useable. The result of data analysis is presented thus;

Table 1: Model Summary

\begin{tabular}{rrrrr}
\hline Model & R & R Square & $\begin{array}{c}\text { Adjusted R } \\
\text { Square }\end{array}$ & $\begin{array}{c}\text { Std. Error of the } \\
\text { Estimate }\end{array}$ \\
\hline $.914^{\mathrm{a}}$ & .836 & .833 & .75028
\end{tabular}

a. Predictors: (Constant), Recognition, Involvement, Peace of mind, Hedonics, Moment of truth

Table 2: ANOVA

\begin{tabular}{|c|c|c|c|c|c|c|}
\hline Model & & Sum of Squares & df & Mean Square & $\mathrm{F}$ & Sig. \\
\hline & Regression & 1043.889 & 5 & 208.778 & 370.887 & $.000^{\mathrm{b}}$ \\
\hline & Residual & 205.464 & 366 & .563 & & \\
\hline & Total & 1249.353 & 371 & & & \\
\hline
\end{tabular}

a. Dependent Variable: Reputation

b. Predictors: (Constant), Recognition, Involvement, Peace of Mind, Hedonics, Moment of Truth

Table 3: Coefficients

\begin{tabular}{|c|c|c|c|c|c|}
\hline \multirow[b]{2}{*}{ Model } & \multicolumn{2}{|c|}{ Unstandardized Coefficients } & $\begin{array}{l}\text { Standardized } \\
\text { Coefficients }\end{array}$ & \multirow[b]{2}{*}{$\mathrm{t}$} & \multirow[b]{2}{*}{ Sig. } \\
\hline & B & Std. Error & Beta & & \\
\hline (Constant) & .389 & .421 & & .925 & .356 \\
\hline Peace of Mind & .716 & .137 & .427 & 5.214 & .000 \\
\hline Hedonics & .107 & .142 & .062 & .755 & .451 \\
\hline Involvement & .705 & .138 & .423 & 5.119 & .000 \\
\hline Moment of Truth & .308 & .144 & .177 & 2.139 & .033 \\
\hline Recognition & .096 & .035 & .059 & 2.727 & .007 \\
\hline
\end{tabular}

a. Dependent Variable: Reputation

\subsection{Discussion of findings}

The multiple regression analysis revealed that the collective relationship of the independent variables in the model and the dependent variable was strong at $\mathrm{R}=0.914$. According to the coefficient of determination $\mathrm{R}^{2}=$ 0.836 and the adjusted coefficient of determination; adjusted $\mathrm{R}^{2}=0.833$, the four customer service experience 
variables (hedonics, peace of mind, involvement, moment of truth, and recognition) explained approximately $84 \%$ of variance in hotel reputation. This means that Customer service experience dimensions considered in this study are $84 \%$ collectively responsible for Hotel reputation.

Since the value of $\mathrm{R}^{2}$ and adjusted $\mathrm{R}^{2}$ are close as adjusted $\mathrm{R}^{2}$ decreased by only 0.003 points, the regression model of this study is said to have a good explanatory power of the dependent variable. In addition, the significant F-ratio at $F=370.887, \mathrm{p}<0.000$ suggest that the results of the regression model could not have occurred by chance and that the combination of all the independent variables significantly predicted the dependent variable.

To assess the relative importance of each independent variable in determining the value of dependent variable, beta coefficients are provided on the Coefficient Table (Table 4). Accordingly, the 5 dimensions of the independent variable showed positive significant influence on hotel reputation. The variable; Peace of Mind $\mathrm{X}_{2}(\mathrm{Pm})$ had the highest statistically significant standardized coefficient of $\beta=0.716$, $\mathrm{p}$-value $=0.000$. Therefore, this was the most important independent variable that had the highest impact on Hotel Reputation. This finding can be interpreted that every 1-unit change in Peace of Mind will lead to 0.716 change in Hotel Reputation. However, since the $\mathrm{p}$-value $=0.000<0.05$, it is concluded that there is a significant relationship between Peace of Mind and the reputation of Hotels.

It was followed by the variable Customer Involvement $\mathrm{X}_{3}$ (Inv), which has a statistical standardize coefficient of $\beta=0.705$, $\mathrm{p}$-value $=0.000$, indicating that customer involvement in service delivery added up to their experience and was the second important consideration that was most likely to influence hotel reputation. This finding can be interpreted that every 1-unit change in customer involvement will lead to 0.705 change in Hotel Reputation. However, since the $\mathrm{p}$-value $=0.000<0.05$, it is concluded that there is a significant relationship between customer involvement and the reputation of Hotels.

Moment of truth $\mathrm{X}_{4}(\mathrm{Mt})$ was statistically significant with a standardized coefficient of $\beta=0.308$, $\mathrm{p}$ value $=0.033$. This finding can be interpreted that every 1 -unit change in experiences gathered during the Moment of truth will lead to 0.308 change in Hotel Reputation. However, since the $p$-value $=0.033<0.05$, it is concluded that there is a significant relationship between experience gathered by the customer in the cause of moment of truth and the reputation of Hotels.

Customer recognition (Reg) also indicated a statistically significant standardized coefficient of $\beta=0.096$, $\mathrm{p}$ value $=0.007$. This finding can be interpreted that every 1 -unit change in Customer recognition will lead to 
0.096 change in Hotel Reputation. However, since the $\mathrm{p}$-value $=0.007<0.05$, it is concluded that there is a significant relationship between customer recognition and the reputation of Hotels.

The least important independent variables in this regression model was Hedonics $\mathrm{X}_{1}(\mathrm{Hed})$ which had a coefficient of $\beta=0.107$, at $p=0.451>0.05$, this indicates that the customer service experience dimension 'Hedonics' had the least impact on Hotel Reputation. Thus, its impact was not statistically significant, as the p-value $=0.451>0.05$.it is concluded that there is no significant relationship between Hedonics and the reputation of Hotels.

However, since all variables were considered together, deletion of one independent variable (although not significant) can affect the significance levels of other independent variables (Leech, Barett, and Morgan, (2005). Hence it can be concluded that the multiple regression model in this study has produced adequate and significant results pointing that Peace of mind, Customer involvement, moment of truth and customer Recognition can be used as significant predictors of Hotel reputation. Based on the regression analysis, the resulting regression equation shows;

$\mathrm{Hr}=0.389+0.107 \mathrm{Hd}+0.716 \mathrm{Pm}+0.705 \mathrm{Inv}+0.308 \mathrm{Mt}+0.096 \mathrm{Reg}$

\subsection{Conclusion}

The primary aim of this study is to ascertain the level of relationship that exist between customer service experience and the reputation of hotels in Akwa Ibom State. The study analyses whether customer service experience dimensions (hedonics, peace of mind, involvement, moment of truth, and recognition) were collectively significant predictors of the reputation of hotels in Uyo the Akwa Ibom State capital. Discussions based on findings of the study shows that customer service experience is a combination of dimensions that involve both direct and indirect encounter with the hotel services. Respondents however placed higher priorities on their peace of mind, physical comfort, security, involvement and recognition among other positive features that thrilled their lodging experience.

Customers' overall experiences of hotel services are however gathered from the moment the customer makes the decision of lodging, to the point he considers options on available services, to considering offers and service condition of the provider, actually encountering the service, up to the point of checking out, and sharing opinion about the service encounter with others. Therefore, measuring customer service experience with the reputation of hotels provides a good measure of service experience marketing. Findings in this study 
are in consonance with Nitin, Seetharaman, Vidyalakshmi and Alison (2018) who emphasis that Consumers and customers are in control and as demands continuously evolve, it is essential for hotel service providers to keep up with the current trends and identify future trends in order to deliver the best value to customers that would better enhance a positive experience during service encounter. This study findings also agree with Amoah, (2016), who indicate that customers are no longer merely satisfied by high levels of service quality, but desire overall experiences of high quality. Thus, experience quality associated with guesthouses and hotel services should place more emphasis on peace of mind, customer involvement, moment of truth and recognition of customers as they are important parts of service experience quality.

\subsection{Recommendations}

It is recommended that hotels should prioritize providing services that will impact positively on the customers during their stay as these collective impressions build up customers experience and post service consumption behaviors. To this end, hotels should identify what customers expect from their services and move towards providing them, giving more attention to enhancing their peace of mind, customer recognition, enhancing positive experience during moment of Truth (service encounters) and involve customers in their services as their opinions counts on what they want or expect from hospitality services. In addition, Hotels should train their staff on customer relations. The front-line staff, in particular should be mostly trained and retrained in this area because of the frequency of contact with customers. The training could be in-house or external. Hotels should not relent in their effort at providing comfort and security for the customers. As we find that customers lay emphasis on peace of mind in most hotel services they seek. This entails the provision for all round security, safety, comfort and the likes.

Finally, hotels should work on their reputation. They should get involved in activities that give them a good name in the environs where they operate. In other words, they should work on their public relations. Where necessary, Public Relations (PR) experts should be consulted or employed to work for the organizations. Providing some community service may not be too much in their attempt at building a favorable image. It is on record in marketing literature that customers who encounter favorable services are likely to engage in word of mouth promotion, develop long term relationships with the hotel and show more intent to repurchase the service (Kotler and Kelvin 2009). One way of building a favorable reputation is through the provision of quality services to their customers to enhance a better post service behavior like favorable word of mouth recommendations, customer loyalty, and satisfaction among customers. 


\section{References}

Ajanović, B. \& Cizel, R., Çizel, E. (2015). Which hotel attributes matter for mass Tourist: A qualitative research on Tourists' review on trip advisor. International Journal of Social Sciences, 1(1), 632-642.

Ajanović, E. \& Çizel, B. (2015). What makes a successful Hotel reputation management strategy: qualitative research on Tripadvisor Hotel reviews. Journal of tourism destination competitiveness, 182-186.

Amoah, F. (2016). Experience quality dimensions and customer perceptions: A case study of guesthouses in Ghana. African Journal of Hospitality, Tourism and Leisure,5 (4), 1-21.

Biesok, G. \& Wyród-Wróbel, J., (2011). Customer satisfaction - Meaning and methods of measuring. In: H. Howaniec, W. Waszkielewicz (ed.), Marketing and logistic problems in the management of organization, 23-41.

Boo, H., C. (2003). Brand alliance model: The moderating role of consumption goals and image congruency in consumers' hotel brand evaluations. 3106209 Ph.D., The Pennsylvania State University.

Chen, C., F. (2007). Experience quality, perceived value, satisfaction and behavioural intentions for heritage tourists. Proceedings of the 13thAsia Pacific Management Conference, Melbourne, Australia 2007, $1130-1136$

Ha, J. \& Jang, S., S. (2010). Effects of service quality and food quality: The moderating role of atmospherics in an ethnic restaurant segment. International Journal of Hospitality Management, 29, 520-529.

Havaldar, K., K. \& Dash, M. (2000). A Study on the Importance of Word-of-Mouth Communication to Business Buyers. SSRN Electronic Journal, 1-25.

Helm, S. (2006). Exploring the Impact of Corporate Reputation on Consumer Satisfaction and Loyalty. Journal of Customer Behaviour, 5(1), 59-80.

Henning-Thurau T. (2004). Motive des Lesens von Kundenartikulationen im Internet: Theoretische und empirische Analyse Konsumentenverhalten im Internet. Springer 171-193.

Jain, R., Aagja, J. and Bagdare, S., (2017). Customer experience; A review and research agenda. Journal of Service Theory and Practice, 27(3), 642-662.

Jayawardena, C. C., Lawlor, F., Grieco, J. C., Savard, M. \& Tarnowski, M., (2013). Challenges and innovations in hotel operations in Canada. Worldwide Hospitality and Tourism Themes, 5, 177-189.

Jeong E. \& Jang, S.S. (2011). Restaurant experiences triggering positive electronic word-of-mouth (eWOM) motivations. International Journal of Hospitality Management, 30, 356-366.

Josiam, B. M. \& Henry, W. (2014). Entertainment: Utilitarian and hedonic motivations for patronising fun experience restaurants. Procedia, Social and Behavioural Sciences, 144, 187-202. 
Kandampully, J. \& Suhartanto, D. (2000). Customer loyalty in the hotel industry: the role of customer satisfaction and image. International journal of contemporary hospitality management, 12(6), 346351.

Kandampully, J., Zhang, T.C. \& Jaakkola, E. (2018). Customer experience management in hospitality; A literature synthesis, new understanding and research agenda. International Journal of Contemporary Hospitality Management, 30(1), 21-56.

Khan, I., Garg, R.J., \& Rahman, Z., (2015). Customer Service Experience in Hotel Operations: An Empirical Analysis. Procedia - Social and Behavioural Sciences, 189, 266 - 274.

Kim, J. H., Ritchie, B. J. R. \& McCormick, B., (2012). Development scale to measure memorable tourism experiences. Journal of Travel Research, 51(12), 11-25.

Klaus, P. \& Maklan, S. (2013). Towards a better measure of customer experience. International Journal of Market Research, 55(2), 227-246.

Leech, N. L., Barett, K. C. \& Morgan, G. A., (2005). SPSS for Intermediate Statistics: Use and Interpretation, (2nd Ed), New Jersey: Lawrence Erlbaum Associates Publishers.

Lemke, F., Clark, M. \& Wilson, J., (2011). Customer experience quality: An exploration in business and consumer contexts using repertory grid technique. Journal of the Academy of Marketing Science, 39, 846-869.

Loo, T., \& Davies, G., (2006). Branding China: The ultimate challenge in reputation management? Corporate Reputation Review, 9, 198-210.

Maklan, S. \& Klaus, P. (2011). Customer experience: are we measuring the right things? International Journal of Market Research, 53(6), 771-792.

Mmutle, T. \& Shonhe, L. (2017). Customers' perception of Service Quality and its impact on reputation in the Hospitality Industry. African Journal of Hospitality, Tourism and Leisure, 6(3), 1-25.

Muzamil, M., Qadeer, A., Makhija, P. \& Jahanzeb, A. (2018). Impact of Different Factors in Creation of Word of Mouth at Hospitality Industry. Journal of Hotel \& Business Management, 7(1), 1-7.

Nikou,S., Selamat, H.B., Yusoff, B.C.M. \& Khiabani, M.M. (2016). Corporate/Hotel Image, Customer Satisfaction, and Customer Loyalty: A Literature Review (1983- 2013). International Journal of Research in Management, 6(6), 43-56.

Nitin P., Seetharaman, A. Vidyalakshmi N. \& Alison D. C. (2018). Changing Dimensions of Customer Experience. Research Journal of Economics, 2(1), 1-7.

Oladele, O.P., Yakibi, A.A., Akinruwa, T.E. \& Ajayi, O.M. (2019). Influence of facilities on Customer patronage among selected Hotels in Southwest, Nigeria. Academy of Strategic Management Journal, $18(1), 1-9$.

Otto, J. E. \& Ritchie, J. R. B. (1996). The service experience in tourism. Tourism Management, 17(3), 165174. 
Ou, W.M., Abratt, J.M. \& Dion, P. (2006) The influence of Retailer Reputation on Store Patronage. Journal of Retailing and Consumer Services, 13, 221 - 230.

Payne A, Christopher M, Clark M. \& Peck, H. (2003). Relationship Marketing for Competitive Advantage -Winning and Keeping Customers. Oxford: Butterworth-Heinemann.

Pine, J. \& Gilmore, J. (1998). The Experience Economy. Boston, Harvard Business School Press.

Ponsignon, F., Klaus, P. \& Maull, R.S. (2015). Experience co-creation in financial services: An empirical exploration. Journal of Service Management, 26(2), 295-320.

Prahalad, C. K. \& Ramaswamy, V. (2004). Cocreation experiences: The next practice in value creation. Journal of Interactive Marketing, 18(3), 5-11.

Qoura, O. \& Khalifa, G.S. (2013). The Impact of Reputation Management on Hotel Image among Internal Customers: The Case of Egyptian Hotels. Journal of Faculty of Tourism and Hotels, Fayoum University, 7(2), 261-270.

Sarpong, S., 2016. The Service Industry and the "Moment of Truth": The Quest for the Holy Grail. Athens Journal of Tourism, 3, (1), 25-40.

Sasson, R. (2014). Peace of mind [Online]. Available: http://www.successconsciouness.com/peace_mind.html . Accessed 28 February 2020.

Schembri, S., 2006. Rationalizing service logic, or understanding services as experience? Marketing Theory, 6 (3), 381- 392 .

Schmitt, B. (2010). Experiential marketing: Concepts, frameworks and consumer insights. Foundation of Trends in Marketing, 5(2), 55-112.

Strauss B. \& Mang P. (1999). Culture Shocks' in inter-cultural service encounters? Journal of Service Marketing, 13(4/5), 329-346.

Verhoef, P.C., Lemon, K.N., Parasuraman, A., Roggeveen, A., Tsiros, M. \& Schlesinger, L.A. (2009). Customer experience creation: determinants, dynamics and management strategies. Journal of Retailing, 85(1), 31-41.

Weeks, R.V. (2015). Managing the services encounter: the moment of truth. Journal of Contemporary Management, 12, $360-378$.

Wu, H. C. \& Li, T. (2014). A study of experiential quality, perceived value, heritage image, experiential satisfaction, and behavioural intentions for heritage tourists. Journal of Hospitality and Tourism Research, 42(1), 1-17.

Zeithaml, V.A. \& Bitner, M.J. (2003). Service Marketing. New York: McGraw-Hill. 